DOI: 10.2478/v10129-009-0001-y

Barbara Wiewióra

Plant Breeding and Acclimatization Institute, Radzików, Poland

\title{
LONG-TIME STORAGE EFFECT ON THE SEED HEALTH OF SPRING BARLEY GRAINS
}

\begin{abstract}
Seeds of 5 cultivars of spring barley, originated from field experiments conducted in 2000 at Radzików, were tested immediately after harvest and after three, four and five years of storage in uncontrolled conditions, for incidence of seed-borne fungi with special regard to "field fungi" (Bipolaris sorokiniana and Fusarium spp.) and "storage fungi" (species of Penicillium and Aspergillus). The studies showed that barley seeds were infected before storage by numerous fungi as well as the saprophytes: Alternaria alternata, Acremonium spp,Acremoniella atra and the pathogens: Bipolaris sorokiniana and ten Fusarium species. The analysis after storage showed that the frequency of fungal infection had changed. The occurrence of some fungi was significantly affected by the period of storage. An increase of infection by species of Penicillium and Aspergillus known as "storage fungi" was detected on seeds after storage, especially after four years. At the same time, isolation of species of Fusarium and Bipolaris sorokiniana from these seeds decreased. Differences in number of 'field' and 'storage' fungi were found in dependence on period of storage, also. The smallest infection by Bipolaris sorokiniana and Fusarium was observed on seed after five years of storage.
\end{abstract}

Key words: 'field' and 'storage' fungi, seed-borne fungi, spring barley, storage

\section{INTRODUCTION}

Long lasting storage of seed has increasing importance to cut capital investments and save labour cost in initial breeding, especially in breeder's seed multiplication scheme. Some breeders claim that the best way to preserve homogeneity of seed is to produce breeder's seed once during growing the variety and keep it in special storage under controlled conditions. Every year a necessary amount of seed is taken from storage and is used in multiplication (Ruza and Linina, 2000).

The most important problem during storage is micoflora contaminating or infecting seeds. Microorganisms on stored seeds can influence seed quality, decreasing germination or growing energy, so seeds should be checked at regular intervals during storage for damage due to storage fungi in order to take preventive measures.

Communicated by Ryszard Górecki 
Many microorganisms are associated with barley seeds (Błaszkowski and Piech, 2002) and they may remain viable in seed lots for many years (Christensen, 1963). Some of them colonize seed - coat (f.eg. Alternaria spp., Fusarium spp., Bipolaris spp.) or floral tissues (ergot). The colonization of seeds by fungi depends primarily upon suitable weather conditions during plant growth (Łacicowa and Pięta, 1998).

Fungi that attack seeds are classified into either 'field' or 'storage fungi' on the basis of their ecological requirements. Field fungi invade seeds either during development or after maturity but before harvest. Generally, damage caused by 'field fungi' occurs in the field, with little or no damage occurring during storage. 'Storage fungi' are adapted to live and grow without free water, and some not only endure but require an environment without free water. These fungi normally do not play any role in disease development in field but play a major role in seed deterioration in storage. They are responsible for major manifestations of deterioration in stored seeds as a decrease in germinability, discoloration, biochemical changes, heating, mustiness and total decay and mycotoxin production. These changes reduce grade and price, contributing to customer dissatisfaction when the grain is marketed (Agarwal and Sinclair, 1997).

The aim of this study was to determine the effect of long-time storage on health status, especially with regard to occurrence of 'field' and 'storage fungi' on spring barley seed, which may account for reduction on sowing value.

\section{MATERIALS AND METHODS}

Seeds of 5 cultivars of spring barley originated from field experiments conducted in the year 2000 at Radzików were tested immediately after harvest and after storage for incidence of seed-borne fungi, especially pathogens. The seeds of Rastik (naked) and Rataj, Rodion, Rasbet, Scarlett (hulled) with moisture content about $10 \%$ were placed in paper bags and kept in uncontrolled conditions - at variable air humidity between 30 to $50 \%$ and temperatures between 15 to $25^{\circ} \mathrm{C}$. The seed health after three, four and five years of storage in these conditions was examined.

The mycological assays were carried out on 200 seeds of each cultivar. Seeds were disinfected with $1 \% \mathrm{NaOCl}$ for $10 \mathrm{~min}$ and then washed with sterile water three times. Disinfected seeds were placed on Potato Dextrose Agar (PDA) medium with $0.003 \%$ streptomycin sulphate. Fungal colonies were grown at $20^{\circ} \mathrm{C}$ in alternating cycle of $12 \mathrm{~h}$ NUV light $(360 \mathrm{~nm})$ and $12 \mathrm{~h}$ darkness. Developed colonies were transferred to PDA plates and were incubated in above - mentioned conditions to stimulate sporulation. Fungi were identified after $15-20$ days of incubation according to the descriptions of Chidambaram et al. (1974), Ellis (1971), Kwaśna et al. (1991), Malone and Muskett (1997), Matur and Cunfer (1993). Data were presented as mean num- 
ber of colonies of 100 seeds from 5 cultivars in 4 replication (50 seeds in every replication were tested). The values were subjected to statistical analysis of variance (ANOVA), followed by mean separation by Tukey's multiple range test.

Table 1

Microorganisms detected on barley seeds before and after storage in uncontrolled conditions (mean number of colonies /100 seeds from five cultivars)

\begin{tabular}{|c|c|c|c|c|}
\hline \multirow{2}{*}{ Microorganisms } & \multirow{2}{*}{$\begin{array}{l}\text { Before } \\
\text { storage }\end{array}$} & \multicolumn{3}{|c|}{ After storage for: } \\
\hline & & 3 years & 4 years & 5 years \\
\hline Acremoniella atra (Corda) Sacc. & 7.6 & - & - & - \\
\hline Acremonium spp. & 10.6 & 0.1 & - & 0.1 \\
\hline Alternaria alternata (Fr.) Keissler & 66.4 & 26.2 & 5.1 & 17.8 \\
\hline Aspergillus spp. & 0.3 & 3.8 & 17.9 & 5.2 \\
\hline Bipolaris sorokiniana (Sacc.) Shoem. & 25.6 & 17.0 & 12.5 & 5.2 \\
\hline Chaetomium spp. & - & 0.1 & 0.6 & 13.4 \\
\hline Cladosporium herbarum (Pers.) Link ex Fr. & 0.9 & 0.2 & 0.1 & 0.8 \\
\hline Drechslera graminea (Rab. Ex Schlecht.) Shoem. & - & 0.1 & 0.3 & 0.3 \\
\hline Drechslera teres (Sacc.) Shoem. & - & 0.8 & 0.6 & 3.7 \\
\hline Epicoccum purpurascens Ehrenb. ex Schlecht. & 1.9 & 0.1 & 0.5 & 1.4 \\
\hline Fusarium avenaceum (Fr.) Sacc. & 0.1 & - & - & - \\
\hline Fusarium culmorum (W.G. Smith) Sacc. & 6.2 & 0.4 & 0.1 & - \\
\hline Fusarium equiseti (Corda) Sacc. & 5.8 & 0.7 & 0.6 & - \\
\hline Fusarium graminearum Schwabe & 1.3 & - & - & - \\
\hline Fusarium moniliforme Sheldon emend. Snyd. et Hans. & - & 0.4 & - & - \\
\hline Fusarium oxysporum Schlecht. emend. Snyd et Hans. & 2.8 & 0.3 & - & - \\
\hline Fusarium poae (Peck) Wollenw. & 18.2 & 0.3 & - & - \\
\hline Fusarium semitectum Berk. et Rav. & 1.5 & - & - & - \\
\hline Fusarium sporotrichioides Sherb. & 0.2 & - & - & - \\
\hline Fusarium tricinctum (Corda) Sacc. & 13.3 & - & - & - \\
\hline Mucor spp. & 0.3 & 0.1 & 0.1 & 0.3 \\
\hline Papularia arundinis (Corda) Fr. & 0.7 & - & - & - \\
\hline Penicillium spp. & 0.1 & 0.8 & 1.6 & 1.8 \\
\hline Sordaria fimicola (Rob.) Ces. \& de Not. & 0.1 & 0.6 & 0.8 & 1.3 \\
\hline Stemphylium botryosum Wallr. & 0.3 & 0.1 & 0.2 & 0.9 \\
\hline Stemphylium consortiale (Thüm.) Groves \& Skolko & 1.7 & 1.8 & 0.2 & 1.9 \\
\hline Trichoderma viride Pers. ex Fr. & 0.1 & 0.1 & 0.1 & - \\
\hline Other & 2.2 & 1.2 & 2.4 & 2.9 \\
\hline Bacteria & 14.4 & 29.1 & 37.4 & 40.0 \\
\hline Total infection & 182.6 & 84.3 & 81.1 & 97.0 \\
\hline
\end{tabular}




\section{RESULTS}

The studies showed that barley seeds tested immediately after harvest were infected by numerous fungi (Table 1). Among them were the saprophytic fungi: Alternaria alternata, Stemphylium spp, Cladosporium spp, Epicoccum purpurascens and the pathogens: Bipolaris sorokiniana and ten species of Fusarium. Colonies of bacteria were also observed. The most abundant fungi were saprophytes and weak parasites, such as: Alternaria alternata (mean 66.4 colonies/100 seeds), Acremonium spp. (mean 10.6) and Acremoniella atra (mean 7.6). Pathogenic fungi were represented by Bipolaris sorokiniana and Fusarium spp. Mycological assays showed that $B$. sorokiniana infected seeds of barley before storage in 25.6 colonies/100 seeds. Differences in seed infection by this fungus were found among cultivars. Seed infection ranged from 22.5 in Rastik to 30.0 colonies/100 seeds in Rasbet cultivar (Fig. 1). On these seeds more abundantly occurred Fusarium spp. also (mean 49.4 colonies/100 seeds). Among ten isolated species of Fusarium: F. poae, F. tricinctum, F. culmorum and $F$. equiseti were the most frequent ones. In naked seed of Rastik cultivar Fusarium fungi were isolated less frequently (mean 37.0 colonies/100 seeds) (Fig. 2).

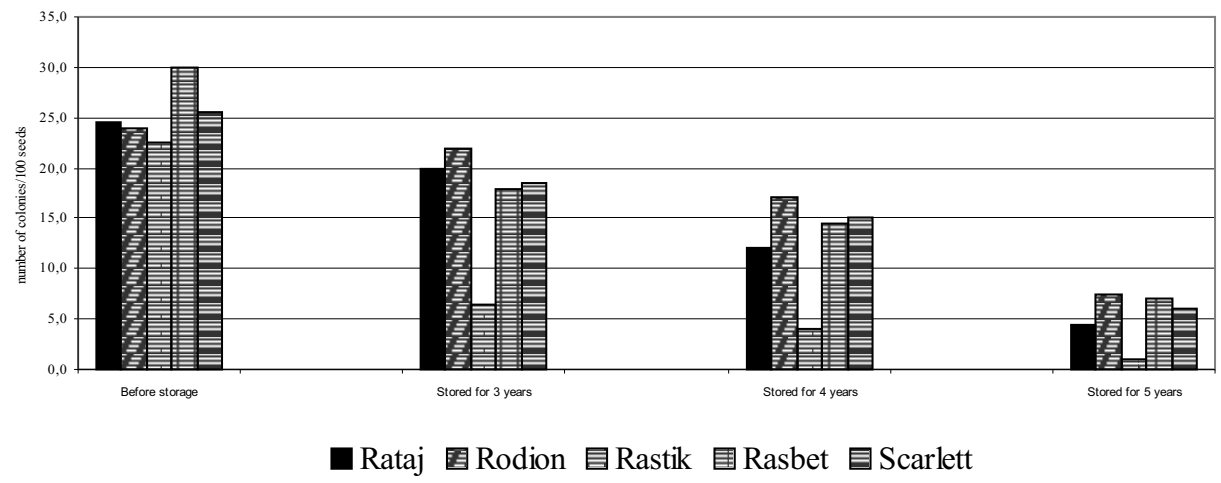

Fig. 1. Seed infection by Bipolaris sorokiniana before and after storage in uncontrolled conditions. $\operatorname{LSD}^{\mathrm{T}}{ }_{0.05}$ for period of storage $=4.95, \mathrm{LSD}_{0.05}$ for cultivars $=5.89$

Health of barley seed tested after storage was differed in comparison to seed health before storage. It was found that saprophytes occurred in small number on stored seeds than on seeds tested immediately after harvest (Table 1). After three years of storage, isolation of A. alternata was reduced by $60.6 \%$ and after four and five years of storage by about 70-90\%. Isolation of Acremonium spp. and A. atra decreased also or those fungi were not observed on seeds at all. Af- 
ter storage bacteria were found on seed in larger number (mean from 29.1 to 40.0 colonies $/ 100$ seeds depending on period of storage) than there were isolated from seed tested immediately after harvest (mean 14.4). The highest seed infection of bacteria occurred on seed tested after five years of storage.

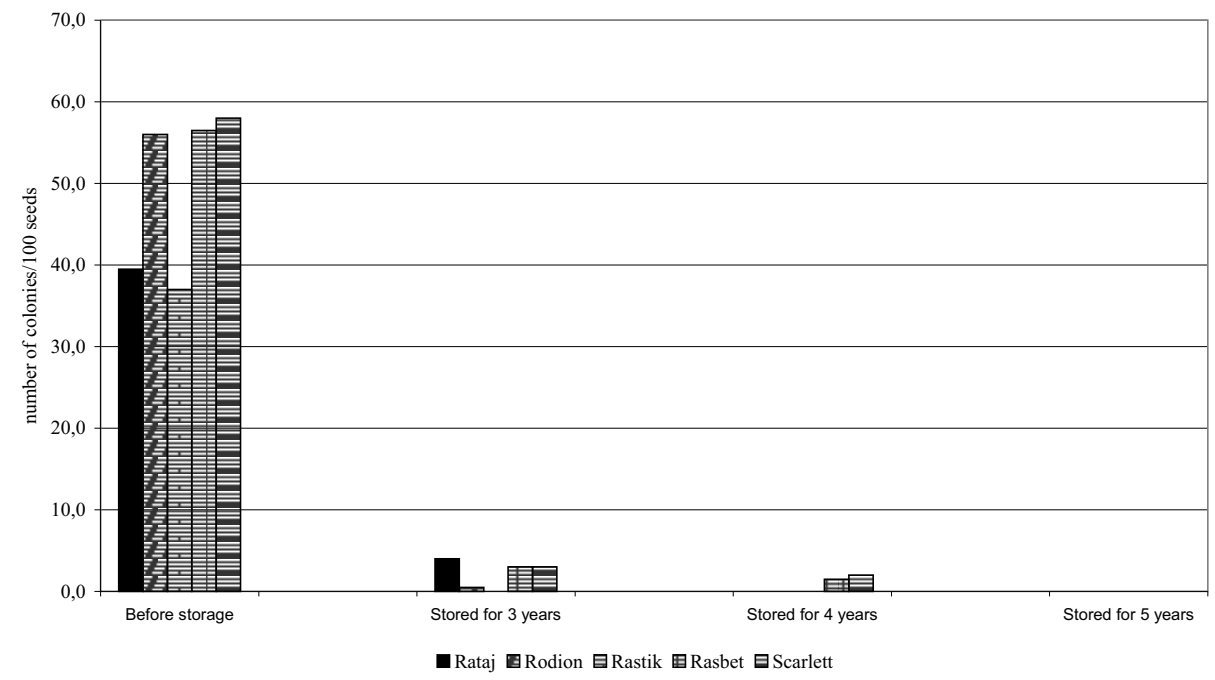

Fig. 2. Seed infection by Fusarium spp. before and after storage in uncontrolled conditions. $\operatorname{LSD}^{\mathrm{T}}{ }_{0.05}$ for period of storage $=3.85, \mathrm{LSD}^{\mathrm{T}}{ }_{0.05}$ for cultivars $=4.58$

The study showed that occurrence of Bipolaris sorokiniana and Fusarium spp. had changed during long-time storage (Fig. 1 and Fig. 2). B. sorokiniana was found in smaller number on seeds after storage: mean 17.0 colonies/100 seeds after three years of storage, 12.5 after four years of storage and 5.2 after five years of storage, than on seeds before storage: mean 25.6 infected seeds $\left(\mathrm{LSD}^{\mathrm{T}}{ }_{0.05}=4.95\right)$. The lowest infection of $B$. sorokiniana at the whole test duration was observed on Rastik cultivar. Number of isolates from naked seeds of this cultivar after storage ranged from 1.0 to 6.5 colonies/100 seeds depending on period of storage. Other cultivars were infected more abundantly: from 18.0 to 22.0 colonies/ 100 seeds after three years of storage, from 12.0 to 17.0 after four years and from 4.5 to 7.5 colonies $/ 100$ seeds after five years of storage (Fig.1).

The similar observations were made for fungi from Fusarium genera. Infection by Fusarium spp. was reduced after storage. The occurrence of these fungi before storage ranged from 37.0 to 58.0 colonies/100 seeds (mean 49.4). After three years of storage mentioned value ranged from 0.0 to 4.0 colonies/100 seeds (mean 2.1) depending on cultivar. Higher reduction of number of Fusarium isolates was noted after four years of storage and ranged from 0.0 to 2.0 colonies/100 seeds (mean 0.7) (Fig. 2). These fungi were not found on seeds after five years of storage at all. Differences in seed infection 
by Fusarium spp. were found among cultivars. After three years of storage the naked seeds of Rastik cultivar were free from these fungi. The same results were obtained for Rataj and Rodion seeds, but after four years of storage. Differences between period of storage were statistically significant, also $\left(\mathrm{LSD}_{0,05}^{\mathrm{T}}=3.85\right)$.

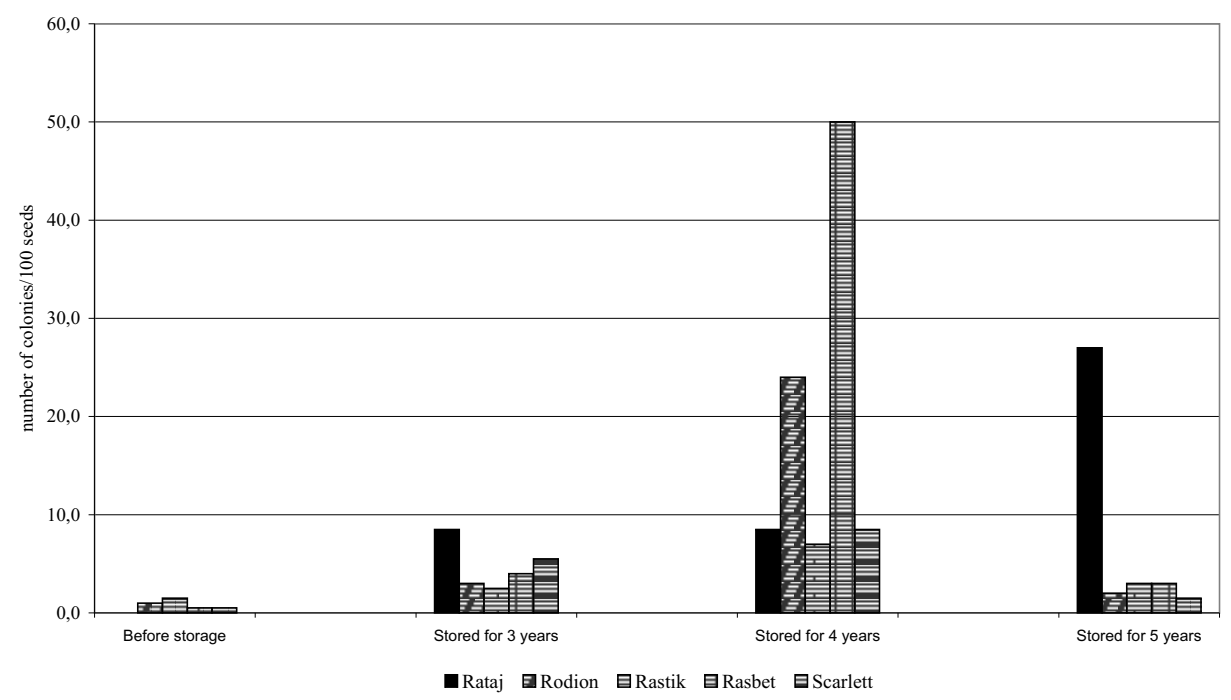

Fig. 3. Occurrence of "storage" fungi (Aspergillus spp., Penicillium spp., Mucor spp.) on barley seeds before and after storage in uncontrolled conditions.

An increase of infection by species of Penicillium, Mucor and Aspergillus known as "storage fungi" was detected on stored seeds (Fig. 3). Seeds after harvest were infected by Penicillium spp. mean in 0.1 colonies/ 100 seeds and occurrence of Mucor spp. was mean 0.3 colonies/100 seeds. Fungi from Aspergillus species occurred on seeds only in 0.3 colonies/ 100 seeds also. After storage infection by Aspergillus spp. increased by 3.8 colonies/100 seeds after three years, by 17.9 after four years and 5.2 after five years. Occurrence of Penicillium spp. after storage increased at lower rate, than fungi of Aspergillus species (mean from 0.8 to 1.8 colonies/100 seeds). Mucor fungi were observed on stored seed in the same amount that on seed tested before storage. The statistical analysis showed that changes in occurrence of 'storage fungi' on seeds after harvest and after storage were significant $\left(\operatorname{LSD}_{0.05}^{\mathrm{T}}=3.98\right)($ Table 2).

The statistical analysis revealed highly significant differences between cultivar and seed infection by such fungi as: B. sorokiniana, Fusarium spp. and "storage fungi" belonging to genera Penicillium, Mucor and Aspergillus (Table 2). The analysis also showed that period of seed storage significantly influenced on the frequency of seed infection by some fungi and pointed out 
the interaction between cultivar and period of storage in seed infection by Fusarium spp., "storage fungi" and total microorganisms (Table 2).

Table 2

Analysis of variance (ANOVA) for cultivars and period of storage influencing the occurrence of some fungi in barley seeds

\begin{tabular}{lrrc}
\hline \multicolumn{1}{c}{ Fungi } & $\begin{array}{c}\mathrm{F} \text { value } \\
\text { for cultivars } \\
(\mathrm{A})\end{array}$ & $\begin{array}{c}\mathrm{F} \text { value } \\
\text { for period } \\
\text { of storage }(\mathrm{B})\end{array}$ & $\begin{array}{c}\mathrm{F} \text { value for } \\
\text { interaction } \\
(\mathrm{A} \times \mathrm{B})\end{array}$ \\
\hline Total microorganisms & $53.48^{* *}$ & $460.33^{* *}$ & $4.35^{* *}$ \\
Bipolaris sorokiniana & $6.55^{* *}$ & $41.54^{* *}$ & 0.79 \\
Fusarium spp. & $6.34^{* *}$ & $559.31^{* *}$ & $4.97^{* *}$ \\
'storage fungi' (Aspergillus spp. +Penicillium spp.+Mucor spp.) & $15.16^{* *}$ & $58.46^{* *}$ & $22.24^{* *}$ \\
\hline
\end{tabular}

\section{DISCUSSION}

The studies revealed that seeds of spring barley were infected by numerous fungi, especially saprophytes and weak parasites such as: A. alternata, Acremonium spp. and A. atra. In addition, bacteria were also noticed. Similar results were obtained by Narkiewicz - Jodko (1979) and Błaszkowski and Piech (2002). According to Trojanowska (1988) the saprophytic micoflora, especially Aspergillus and Penicillium, can be used as a rough indicator of the seed quality.

In all tested seed samples Alternaria alternata was the most popular saprophytic fungus, which was reported by Knudsen et al. (1995) also. This fungus may be potentially dangerous for plant, because it can produce a toxin tenausonic acid, which inhibits roots and sprout elongation and alternariol, delaying seedling development (Baturo, 2002).

Pathogenic fungi were represented by Bipolaris sorokiniana and Fusarium spp. Bipolaris sorokiniana, distinctively from Fusarium spp., is one of the most dangerous pathogens which cause barley disease (Lacicowa and Pięta, 1993). Knudsen et al. (1995) claim 76\% infection of spring barley grain by $B$. sorokiniana. The analyses revealed by Łacicowa (1982) showed that this fungus can limit germination drastically, even to $25 \%$, or the infected grain gives rise to diseased and weak seedlings. B. sorokiniana invaded the hulled grain more frequently than the naked ones. Similar results were obtained also by Narkiewicz - Jodko et al. (2003).

The mycological assay showed that seed of spring barley were also often infected by Fusarium species, especially Fusarium poae, Fusarium tricinctum, Fusarium culmorum and Fusarium equiseti. From these species $F$. culmorum and $F$. tricinctum are considered the most dangerous pathogens of cereals (Mańka, 1989), because can cause seedling disease and damage of root and stem base of older plants (Wakuliński and Chełkowski, 1993). 
This study showed that the frequency of seed infection by fungi had changed during storage. Some fungi were isolated rarely and some of them frequently from stored seeds in comparison to fungi isolated from seed tested before storage. For example the decrease of seed infection by Alternaria alternata, $B$. sorokiniana and Fusarium spp. was observed after storage. At the same time isolation of Aspergillus and Penicillium species from these seeds increased. Similar relationship between seeds storage and contamination by these fungi was reported by Narkiewicz-Jodko (1979), Gabińska et al. (1991) and Narkiewicz-Jodko et al. (2004).

The longevity of fungi dependents on storage conditions, also. Lutey and Christensen (1963) found substantial reduction in percentage of "field fungi" such as Alternaria, Drechslera, and particularly Fusarium in barley kernels kept for a few months at $14 \%$ moisture content at $20^{\circ} \mathrm{C}$. Same conditions and six months of storage reduced viability of Drechslera and Fusarium to 0, and Alternaria from $80 \%$ in the original seed to $10 \%$. When the moisture content was reduced to $12 \%$, all mentioned "field fungi" were present, although in low percentages, after one year of storage at $20^{\circ} \mathrm{C}$. On the other hand, grain stored at $16 \%$ moisture content and $20^{\circ} \mathrm{C}$ and $30^{\circ} \mathrm{C}$ was invaded by "storage fungi" before the "field fungi" died. Data presented here indicated, that $15-25^{\circ} \mathrm{C}$ temperature and $30-50 \%$ moisture conditions of storage significantly influenced on occurrence of 'field' as well as "storage fungi" on barley seeds. On all seed samples examined after storage following "field fungi" were found: Alternaria alternata and Bipolaris sorokiniana, and "storage fungi" from genera Aspergillus and Penicillium. During storage in these condition fungi Fusarium died out faster. Neergaard (1977) claimed that more or less hyaline fungi characterised by thin-walled conidia, mainly Fusarium spp., are usually short-lived and they may often be controlled by storage of the seed for a suitable period of time. On the other hand fungi with strong pigmentation and thick conidial walls, as exemplified by species of Drechslera and Bipolaris, have been found to be quite long-lived.

The reason of changes in quality and quantity of microflora could be antagonistic activity majority of microorganisms known as "storage fungi" in relation to the pathogens (Trojanowska, 2002). These fungi, due to their competitive and hyperparasites properties, may facilitate the control of pathogens or make difficulty in isolation of pathogens. Additionally, Penicillium spp. besides its favourable character based on antagonism towards some pathogens, can produce an antibiotic which is unfavourable to grain germination and young plant development due to their disturbed metabolism (Hasan, 1999).

Preliminary studies of germination capacity and vigour before and after one year of storage indicated changes in value of these factors during storage (Wiewióra, 2006). Data presented there shown that germination capacity depended on infection by pathogens because the seed stored one year with less infection germinated better in comparison to grain before storage, which were stronger infected. Other authors have also found that occurrence of some fungi 
influenced the reduction of germination capacity (Gabińska et al. 1991, Lacicowa 1982, Szyrmer et al. 1984). However analysis of vigour indicated also that even one year of storage provoked reduction of all vigour parameters: plumule and root length and dry weight. Grzesiuk et al. (1990) found acceleration of vigour degradation which was observed in elevated conditions of humidity and temperatures. Germination and vigour are not only depends on seed-health, but also on other factors, mainly physiological and biological seed conditions.

\section{CONCLUSION}

Seeds of spring barley harvested in field experiment were contaminated by saprophytic fungi: Alternaria alternata, Acremonium spp. and Acremoniella atra. The most numerous pathogens on these seeds were $B$. sorokiniana and Fusarium spp. Among ten isolated species of Fusarium the most frequent ones were $F$. poae, $F$. tricinctum, F. culmorum and $F$. equiseti.

Results showed that the frequency of seed infection by fungi changed during storage. Some fungi were isolated rarely and some of them frequently from these seeds. Data presented indicate that occurrence of 'field' and 'storage fungi" depended on period of storage. Seed stored five years were infected in the lowest number by main pathogen Bipolaris sorokiniana. On these seeds Fusarium fungi weren't found at all. Additionally storage fungi from genera Aspergillus and Penicillium occurred more abundantly on these seeds. It was observed also that pathogens were eliminated faster from naked seeds than from hulled ones.

\section{REFERENCES}

Agarwal V.K., Sinclair J.B. 1997. Principles of seed pathology. Second edition CRC Press Inc., Lewis.

Baturo A., 2002: Head healthiness and fungus composition of spring barley harvested grain cultivated under organic, integrated and conventional farming system. Phytopathologia Polonica, No. 26: 73-83.

Błaszkowski J., Piech M., 2002: Comparison of seed-borne fungal communities of naked and husked oats and barley. Phytopathologia Polonica, No. 24:73-76.

Chidambaram S.B., Matur S.B., Neergaard P., 1974: Handbook on seed health testing. The International Seed Testing Association As - NLH. Norway: 165-207.

Christensen J.J. 1963. Longevity of fungi in barley kernels. Pl. Dis. Rep. 47: 639-642

Ellis M.B., 1971. „Dematiaceous Hyphomycetes“. Commonwealth Mycological Institute. Kew, Surrey, England.

Gabińska K., Narkiewicz-Jodko M., Schneider J., 1991:[Long-time storage effect on the sowing value of winter Triticale grain]. Wpływ wieloletniego przechowywania na wartość siewną pszenżyta ozimego. Biul. IHAR 180, 43-52.

Grzesiuk S., Górecki R., Michalczyk D.J. 1990. Zmiany wigoru nasion motylkowatych drobnonasiennych pod wpływem różnego przechowywania. Biul. IHAR 173-174: 171-174.

Hasan H. A., 1999: Phytotoxicity of pathogenic fungi and their mycotoxins to cereal seedling viability. Kluwer Academic Publishers. Mycopathologia 148(3):149-155.

Knudsen I., Hockenhull J., Jensen D.F., 1995: Biocontrol of seedling diseases of barley and wheat caused by Fusarium culmorum and Bipolaris sorokiniana: effect of selected fungal antagonists on growth and yield components. Plant Pathology 44:467-477.

Kwaśna H., Chełkowski J., Zajkowski P., 1991: Flora Polska. T. XXII. Grzyby niedoskonałe. Strzepczakowe. Gruzełkowate. Sierpik (Fusarium). PAN Warszawa - Kraków: 1-145.

Lutey R.W., Christensen C.M. 1963: Influence of moisture content, temperature and lenght of storage upon survival of fungi in barley kernels. Phytopathology 53: 713-717. 
Łacicowa B., 1982: Zaprawianie fungicydami systemicznymi ziarna jęczmienia jarego porażonego przez Helminthosporium sorokinianum Sacc. Ochrona Roślin 6:6-9.

Łacicowa B., Pięta D., 1993: The effect of recurrent cropping on stem and root diseases and grain yield of spring barley (Hordeum vulgare L.). Rocz. Nauk Rol. s.E, T.20, z.1/2:21-25.

Łacicowa B., Pięta D., 1998: Wpływ temperatury i opadów na udział grzybów w powodowaniu chorób podsuszkowych jęczmienia jarego (Hordeum vulgare L.). Acta Agrobot., 51 (1/2):51-61.

Malone J.P., Muskett A.E., 1997: Seed - borne fungi. Descriptions of 77 fungus species. $3^{\text {rd }}$ Edition. Sheppard J.W. (ed.). ISTA, Zurich: 1-191.

Mańka M., 1989: Patogeniczność wybranych gatunków z rodzaju Fusarium dla siewek zbóż. Roczniki AR w Poznaniu, Rozprawy Naukowe 201.

Matur S.B., Cunfer B.M., 1993: Seed-borne disease and seed health testing of wheat. Jordbrugsforlaget Frederiksberg, Denmark:1-168.

Narkiewicz-Jodko M., 1979: Wpływ wilgotności na zdolność kiełkowania i mikoflorę ziarna zbóż przechowywanego bez wymiany powietrza oraz w atmosferze dwutlenku węgla. Biul. IHAR 135,133-141.

Narkiewicz-Jodko M., Gil Z., Liszewski M., 2003: Effects of cultivation systems and harvest times on the heath of spring barley grain. Phytopatol. Pol. 30: 61-71.

Narkiewicz-Jodko M., Gil Z., Liszewski M., 2004: Wpływ warunków przechowywania na zdrowotność i cechy towaroznawcze ziarna jęczmienia jarego. Pam. Puł. z. 135: 189-198.

Neergaard P. 1977. Seed Pathology. Volume I. The Macmillan Press Ltd, London and Basingstoke.

Ruza A., Linina A., 2000: Changes of grain seed pathogens during lasting storage under diverse conditions. International Seed Health Conference PTFiT, Seed Health as Quality Criterion; Radzików 9-11 October 2000: 52.

Szyrmer J., Rytko G., Grzelak K., Tulo M. 1984. Znaczenie wartości siewnej ziarna w produkcji zbóż. Zeszyty Prob. Post. Nauk Rol. Z. 305: 371-375.

Trojanowska K., 1988: Grzyby z rodzaju Aspergillus i Penicillium jako wskaźnik oceny jakości ziarna zbóż. Rocz. AR Poznań, Rozpr. Nauk. 171: 1-60.

Trojanowska K., 2002: Zagrożenia ze strony mikroflory występującej na ziarnie zbożowym i w jego przetworach. Prz. Zboż.-Młyn. 2: 9-12.

Wakuliński W., Chełkowski J. 1993: Fusarium species transmitted with seed of wheat, rye, barley, oats and triticale. Hod. Rośl. Aklim. Nasien. 37(4):131-136.

Wiewióra B. 2006. Wartość siewna, zdrowotność i skład chemiczny ziarna jęczmienia jarego przechowywanego w różnych warunkach. Biuletyn IHAR 242: 89-103. 